\title{
Strategies and Optimizing the Role of Productive Waqf in Economic Empowerment of the Ummah
}

\author{
Rian Ardiyansyah ${ }^{1}$, Abdurrohman Kasdi ${ }^{2 *}$ \\ ${ }^{1}$ Department of Sharia Economics, State Islamic Institute (IAIN Kudus) \\ ${ }^{2}$ Department of Islamic Family Law, State Islamic Institute (IAIN Kudus)
}

\begin{abstract}
The understanding and empowerment of waqf assets among Muslims has undergone significant changes in both paradigm and operational practices. The development of productive waqf aims to achieve social justice and improve the welfare of people. Therefore, productive waqf has two visions at once, destroying unequal social structures and providing fertile land for the welfare of the people. This research method uses a qualitative method with a descriptive-analytical approach. The data used were secondary data, namely, literature studies or relevant previous research results. The results of his research show that waqf plays an important role as an instrument to empower the economy of the people. Waqf has played an important role in the social, economic, and cultural development of society. There are at least four basic problems with the Islamic da'wah movement. First, the problem of poverty, both in terms of the economy and limited facilities and physical needs, creates a culture of poverty. Second, the twisting of the kemikinan prompts the symptoms of underdevelopment. Third, there was an exclusive and involutive attitude. Finally, the weakness of the institutions for accommodating participation and the weakness of the cooperation mechanism to wage a systematic struggle. Thus, waqf is an alternative that is expected to provide solutions to these problems. Therefore, the optimal management of waqf objects is required.
\end{abstract}

Keywords: Waqf; Productive Waqf; improve the welfare of the Ummah

*Corresponding author: abdurrohmankasdi@iainkudus.ac.id

Received: July 07, 2020; Accepted: January 09, 2021; Published: June 15, 2021

Abstrak: Pemahaman dan pemberdayaan harta wakaf di kalangan umat Islam telah
mengalami perubahan yang signifikan, baik paradigma maupun praktik operasionalnya.
Pengembangan wakaf produktif bertujuan untuk mencapai keadilan sosial dan
meningkatkan kesejahteraan umat. Karena itu, wakaf produktif memiliki dua visi
sekaligus; menghancurkan struktur sosial yang timpang dan menyediakan lahan subur
untuk kesejahteraan umat. Metode peneletian ini menggunakan metode kualitatif dengan
pendekatan deskriptif-eksplanatif- analitis. Data yang digunakan adalah data sekunder 
yaitu studi kepustakaan ataupun hasil penelitian terdahulu yang relevan. Hasil penelitiannya wakaf mempunyai peran penting sebagai salah satu instrumen dalam memberdayakan ekonomi umat. Wakaf telah memerankan peran penting dalam pengembangan sosial, ekonomi, dan budaya masyarakat. sedikitnya ada empat permasalahan dasar pergerakan dakwah Islam. Pertama, masalah kemiskinan baik dari sisi ekonomi maupun keterbatasan sarana dan kebutuhan fisik yang pada urutannya melahirkan budaya kemiskinan. Kedua, sebagai akibat dari lilitan kemikinan mendorong munculnya gejala keterbelakangan. Ketiga, munculnya sikap eksklusif dan involutif. Terakhir, lemahnya kelembagaan penampung partisipasi dan lemahnya mekanisme kerjasama untuk melancarkan perjuangan sistematis. Dengan demikian wakaf menjadi salah satu alternatif diharapkan mampu memberikan solusi dalam penyelesaian masalah tersebut. Maka perlu pengelolaan secara optimal terhadap benda wakaf

Kata kunci: Wakaf; Wakaf Produktif; Pemberdayaan Umat

\section{INTRODUCTION}

Islam, which is based on two points, namely Al Quran and Al Sunnah, is a religion that is complete, perfect, universal, and applicable to all times and places. His teaching was considered sacred by adherents. On the other hand, every religious adherent will try to translate his religious teaching into religious behavior as the actualization of teachings. However, this form of religion is very "human" meaning that it really depends on the level of knowledge and its ability to understand or grasp the side of the teachings, plus factors of customs, environment, and so on.

Waqf is a potential source of funds for the people that need to be developed, utilized, and managed in a professional manner to obtain optimal benefits to alleviate poverty and improve the welfare of the people. To mobilize the potential of waqf, it is necessary to have a partnership between the waqf institution formed by the community and the waqf agency, which is formed by the government in which the members consist of Nazhir in society and the government in a professional manner (Kasdi, 2017).

However, the term productive waqf is not very familiar in the midst of Indonesian society. This can be seen from understandingnIndonesian people who seenwaqf is only limited to giving in formnimmovable property, such as land and nearby buildings for places of worship, graves, boarding school, orphanages, and education only. Utilizationnwaqf objects are still in the rangenon things of a natural physical, so that they do not have an economic impact. The number of possessionsnwaqf in communitynIndonesia has not been able to cope with the poverty problem. This is because the waqf cannot be managed maximally, while the poor from year to year are increasingly improved in urban and rural areas. (Indriati, 2017)

There are two patterns of development yields of productive waqf assets that can be madenby managers: first, the development of waqf for social activities, such as waqf for justicensocial, people's welfare, development, health facilities, public policy advocacy, legal policy, human rights, protectionnchildren, environmental conservation, empowermentnwomen, developmentnarts, and culture. Second, 
development with economic value, such as developing trade, financial investment, developnindustrial assets, property purchases, and so on.

The existing waqf has not touched much on contextual understanding. Waqf is one of the various activities of Islamic economics. Waqf is a problem that has not been extensively investigated. The existing discussion still concentrates on the subject matter of fiqh, philosophy of Shari' ah, usury, financenand Shari' ah banking, and so on. However, theoretical and practical discussions are rare. In terms of collecting public funds, it appears that the discussion centered on the issue of zakat. However, other fields have not received sufficient attention. Many Islamic economic system activities can be undertaken to accumulate public funds. These funds can be collected not only from zakat funds but also from sources such as sadaqah, infaq, waqf, and nso. (Hadi, 2017)

Therefore, there are no other words to minimize the economic disparity of the people, except for withnmaximizing the roles of empowerment institutions that exist. In Islam, we are familiar with waqf institutions and zakat. In its infancy, the economy is quite concerningnThis is actually the role of waqf in addition to instruments other. It can be felt that its benefits are to improve people's lives, particularly in the economic sector, if waqf is managed properly. Allocationnwaqf in Indonesia, which leads to less empowerment of the economy of the people and tends only for the sake of special worship activities are more influenced by limitations; Muslims will understand nwaqf, both regarding the donated property, allotmentnendowments, and nazir waqf. In general, Indonesian Muslims understand that designationnwaqf is only limited to the benefit of nworshipnand things that are usually donenin Indonesia. Mosques, mosques, schools, madrasa, Islamic boarding schools, cemeteries, and nso (Kasdi, 2014)

Thus, it can be said that in Indonesia until now, the potential of waqf as a means does good for interestsnthe community has not been managed and utilized in a manner maximum within the national scope. From practical experience, waqf creates a certain image or perception regarding waqf. First, waqf is generally in the form of objects that are not moving, especially the ground. Second, in reality, the ground built a mosque or madrasa. Third, their use is based on the will of the waqf giver (waqif). other than that interpretation arises that in order to maintain its immutability, the waqf land is prohibited for sale. As a result, in Indonesia, banks do not accept donated land as an admirer. In fact, if donated land can be used, organizations such as NU and Muhammadiyah or university/collegenheight can getnloan funds that are played and produce something. (Al-hadi 2009)

The understanding and empowerment of waqf assets among Muslims has undergone significant changes, either in paradigm or operational practice. At the levelnparadigm, waqf, which was initially only understood as a limited utilization of worship in the form of a mosque and musalla, is currently expanding into exploitation efforts for various goods or objects that are economically productive. Meanwhile, at the practical level, waqf is now starting to develop into a form of valuable use productive and as a means of economic improvement, such as productive waqf for education, hospitals, supermarkets, etc. (Hadi, 2017)

The broader understanding and wealth empowerment this waqf becomes important, especially if it is associated with the concept of developing productive 
waqf that aims to achieve social justice and improve well-being. Therefore, productive waqf has two visions: destroynlame and supplying social structurenfertile land for well-beingnpeople. This vision is the derivation of the philosophy that implies more waqf emphasizenon empowermentnpotential of waqf, so that waqf does not only have a divine dimension but also pro-humanity. This is a more welcoming waqf of the reality of people stricken by poverty, ignorance, and backwardness. (Dikuraisyin, 2020)

There is no doubt that waqf in the history of Islamic civilization has been a pillar of support for the establishment of socio religious institutions for the Muslim community for centuries. This is done through the provision of funds and supporting facilities for religious ritual activities, education, and health. In fact, waqf at that time had significant social functions by providing public facilities, such as roads, bridges, drinking water, parks, cities, and public baths. Waqf has endorsing several social justice, education and social justice initiatives health, and other compatible goalsnwith a paradigm benefit which is also a partnof the orientation of the maqasid asy-syari'ah. The research gap is changing the understanding and empowerment of waqf assets among Muslims that have undergone significant changes, both in paradigm and operational practices. The development of productive waqf aims to achieve social justice and improve the welfare of people. Therefore, productive waqf has two visions at once, destroying unequal social structures and providing fertile land for the welfare of the people.

\section{RESEARCH METHODS}

This study uses a qualitative research model with the assumption of research and development, and the purpose of the research model is gradually researched and developed qualitatively (Sugiyono, 2005). Qualitative is defined as a research method used in the condition of natural objects, and is also called naturalistic, experimental, and ethnographic methods. Research and development are the basic assumptions of research that begin with the introduction, development, and implementation (Sugiyono, 2005).

The obtained data were analyzed using the data analysis model Miles and Hubermannnamely reduction, display, and conclusion (Sugiyono, 2005). In the final stage, all data were analyzed for their validity using the source triangulation technique through checkingnrepeat through the final stage of observation (single source triangulation) and through related theoretical documents, both documents obtained from online media as wellnphysic.

\section{RESULTS AND DISCUSSION Productive Waqf Empowerment}

The above phenomenon encourages waqf managers, the government, and ulama to interpret the meaning of waqf. Waqf is not only understood in the spiritual dimension, but also contains a socio-religious dimension and has the potential to increase the economy and welfarenMuslims. One of the efforts for empowermentnwaqf is to optimize the role of waqf to make it more productive. Waqf has great potential to be developed into productive assets, which in the end 
Ardiyansyah, Kasdi, : Strategies and Optimizing the Role of Productive 65 Waqf ...

are not only able to support servicesnsocio-religious, but also to support various justice initiativesnsocial andneducation.

According to Jaih Mubarok (2008: 15-16), productive waqf is a transformation from professional management of waqf to increase the benefits of waqf. Productive waqf can also be interpreted as a management process for objects to produce maximum goods or services with minimum capital.

According to Mundzir Qahaf, productive waqf transfers assets from consumptive efforts toward production and investment in the form of production capital that can produce and produce something that can be used in the future, either by individuals, groups, or by the general. Thus, productive waqf saves and invests activities simultaneously (Qahaf, 2006)

Said and Lim (2005: 6-7) conducted research on how to empower strategiesnWaqf assets to be productive, according to which there are five (five steps to empower strategiesnwaqf in order to become productive waqf; namely, recognizing the potential for rotationnwaqf assets by looking at the history or waqf models that have been running and doingnupdatenon the waqf system. Second, it facilitates the modern waqf model by applying management techniques waqf, as long as the objectives do not conflict with Sharia principles. Third, promote Islamic philanthropy through waqf, so that waqf can become the backbone for society and potentially play an important role in servicenPublic. In addition, productive waqf can be an alternative in times of crisis when the government is no longer able to meet people's needs. Fourth, modernizing the administration of waqf, so that the management structure waqf can be more efficient, transparent, and responsive, as well as establish technical cooperation and exchange experiences with educational institutions, international organizations, and other countries to develop waqf investment. Fifth, to be productivenwaqf that was previously unproductive by generating commitment from waqf, nadzir, investors, and the surrounding community who know the benefits of waqf.

The emergence of the productive waqf paradigm is the main choice when people are in a downturn of acute poverty. WithnProductive waqf means that existing waqf is given top priority and is aimed at more productive efforts. Of course, with different paradigm measures from consumptive waqf, it gives hopennew to most Muslim communities. This waqf has no intention of directingnwaqf on mahdah a sich worship, but is ratherndirected at productive efforts to solve the problems of the people.

Of course, this productive waqf has a social dimension. Productive waqf is devotednoneself to errornMuslims. Thus, it can be seen from this that waqf is prohumanitarian and not waqf with a dimensionngodliness only. Therefore, what appears in waqf is waqf, which is more welcoming to the reality of Muslims who are hit by poverty, ignorance, and underdevelopment.

Globally, productive waqf has become the main paradigm in managing assets. Call Egypt, Algeria, Sudan, Kuwait, and Turkey have long been managing waqf in a productive direction. For example, in Sudan, the Sudan Waqf Board manages unproductive waqf assets by establishing the nWaqf Bank. Financial institutions are used to assist waqf development projects in establishing business and industrial companies. Another example is to develop the productivity of waqf assets, and the 
Turkish government established the Waqf Bank and Finance Corporation. This institution specifically mobilizes waqf sources and finances various types of joint venture projects.

In addition, in a country where the Muslim population is a minority, developmentnwaqf is no less productive. In Singapore, the waqf assets in Singapore amounted to $\$ 250$ million. To manage it, the Singapore Islamic Council (MUIS) created a subsidiary called Wakaf Real Estate Singapore (Warees). Warees are companyncontractors that maximize waqf assets. Example of empowerment potential, Warees foundedn8-storey building on waqf land. Financing is obtained from loansnSukuk funds of $\$ 3$ million, which must be returned for five years. This building for rent and annual net worth is $\$ 1.5$ million. After three years of running, the loan was paid off. Next, incomenit belongs to the allocated MUISn for the welfare of people.

In Indonesia, developmentnproductive waqf has found its bright point with the passing of Law No. 41 of 2004 concerning waqf and PP. 42 of 2006 on the implementation of Law No. 41 of 2004. Empowerment of productive waqf is characterized by three characteristics: first, management patternsnIntegrated waqf and waqf funds can be allocated for surgical programs. Second, the principles of the nadzir welfare. ProfessionnNadzir is no longer positioned as a social worker, but rathernprofessional workers who live worthy of that profession. Third, the principles of transparency and accountability are discussed. Waqf bodies and waqf institutions must report the entire process of managing funds annually to the community (Antonio, 2007)

\section{Productive Waqf Development Strategy}

Implementing productive waqf requires a strategy that can develop a productive waqf. According to Eddy Khairani, there are several things that can be donated to the productive waqf development strategy:

a. Regulation of laws and regulations: The Directorate General of Islamic Community Guidance continues to do sonregulations in the field of waqf legislation. After the birth of Law Number: 41 of 2004 concerning Waqf and RegulationsnGovernment Number 42 of 2006 concerning Implementation of Law No. 41 of 2004 concerning Waqf, currently a draft regulation of the Minister of Religion on Guidelines for the Implementation of Waqf in Indonesia is currently being prepared. With this PMA, it is hoped that the practice of waqf can run properly for benefitnwell-beingngeneral.

b. Socialization of regulationsnper-Waqf law and a new paradigm of waqf, in order to socialize regulationsnwaqf legislation and nthe new paradigm of waqf in Indonesia, the Directorate General of Islamic Community Guidance didnsocialization through various local and national events, such as: (1) Waqf workshopsncampus community; (2) socialization of cash waqf in the neighborhood BMT and LKS; and (3) management management training nendowments in the Nazhir neighborhood, and others. Socialization was carried out with the aim of informingnto the public in general, and to state officials related to management nwaqf in Indonesia, as well as making mass media as government partners in efforts to empower waqf. 
c. Certification, inventory, and advocacy of waqf assets; To carry outnmandated by Law Number 41 of 2004 concerning Waqf related to securitynwaqf property in Indonesia, the Directorate General of Islamic Community Guidance stipulatesnvarious policies, namely:

Completenthe certification process for waqf lands in various regions that do not have a waqf certificate. The certification of waqf land isnsteps to legally safeguard waqf assets in Indonesia from various interests beyond waqf.

Waqf property inventory throughout Indonesia through a computerized system.

The mapping potential of the waqf property, such that the potential that can be developed can be identified.

Doing advocacy, protectionnand completionnWaqf land disputes with third parties.

d. Enhancement of the quality of Nazhir and the waqf institution; Nazhir and the waqf management institution as the spearhead of management and developmentnwaqf property is givennmotivation and coachingnin to improve management professionalism through various trainings and orientations. Nazhir's quality in Indonesia continues to be givennmotivation and direction in order to donimprove, both regarding managerial abilities and critical individual skillsnin productively empowering waqf.

e. Facilitating partnershipnproductive waqf investment: As a motivator and facilitator, the Directorate General of Islamic Community Guidance facilitates various events in order to build partnerships with potential investors, such as the Investment Coordinating Board (BKPM) and the Chamber of Commerce and Industry (KADIN) in several regions to empower nwaqf productively. Waqf assets in Indonesia are quite large and have the potential to be developed by inviting several third-party agencies interested in developmentnwaqf.

f. Facilitating the formation of the Indonesian Waqf Board (BWI); In order to support managementnand the development of waqf in Indonesia, the Directorate General of Islamic Community Guidance facilitates the formation of the Indonesian Waqf Board (BWI) as an institution that has tasks, including fosteringnagainst Nazhir throughout Indonesia (Khairani, 2013)

Thus, there are six strategies to empower productive waqf, starting from legal products to building networks in the form of partnershipnproductive investment. One of them is cash waqf, which can open up unique opportunities to create investment in order to provide services, religion, educational services, and social services. Savings of rich people can be used in exchange for Cash-Waqf certificates. Development resultsnWaqf obtained from the certificate can be used for purposes as varied as purposesnwaqf itself. Another thing about Cash Waqf Certificate is that it can change old habits where opportunitynwaqf as if only for rich people. (Indriati, 2017). 


\section{Productive Waqf and Empowerment the Economy of the People}

Waqf is a problem that has not been extensively investigated. This is because Muslims have almost forgotten activities originating from waqf institutions. Mismanagement and corruption problems are expected to become the main cause, so that the activities of the representative institution lack interest or are even abandoned by Muslims less than a century ago. (Kurniawan, n.d.)

Waqf is important for empowering the people's economy. In its history, waqf has played an important role in developing social, economic, and cultural communities. The most prominent part of the waqf institution is its role in financing Islamic education and health. Continuitynthe benefits of endowments are very likely to enact productive waqf to support various social and religious activities. In general, productive waqf is only in the form of agricultural land or Perkebenunan, buildings, managed to provide benefits that the results can be used for these activities. Thus, waqf assets have become a source of funds for people and people. (Indriati, 2017)

The Indonesian nation faces two challenges in the runningndevelopment wheel. The gap between the rich and the poor is widening. The tendency to increase depends on the poor to the owners of capital and Indonesia's dependence on developed countries. Sasono added that there were at least four basic problems with movementnda'wah Islam. First, poverty, both in terms of economy or limitationsnphysical means and needs that give birth to a culture of poverty. Second, the result of povertynhence the signs of underdevelopment appear. Third, there is the emergence of an involutive and exclusive nature. Fourth, the weakness of progression to accommodate participation and the weakness of the cooperation mechanism to smooth it outnstruggle. (Kurniawan, n.d.)

Waqf is one of the expected alternatives to provide solutions for solving problems. Thus, management is needed, which is optimal for waqf assets. However, many waqf assets are currently not optimally managed. According to departmental datanThe last religion there is donated land in Indonesia as many as 403,845 locations with an area of 1,566,672,406 M2. Of these, $75 \%$ have been certified as waqf and about $10 \%$ have high economic potential, and there are many that have not been recorded. This indicates a lack of understanding about the assets that are donated to immovable objects and only for purposes worship, such as mosques, prayer rooms, madrassas, funerals, and others. In fact, waqf can be productively managed. For example, the Maintenance Foundation and Expansion Waqf Boarding School Gontor, East Java, and the Waqf Board of the Islamic University of Indonesia, which manage waqf assets productively.

In management efforts, Waqf land is productive, and the role of nazhir waqf is as a person or institution that has the task of managing waqf. Nadzir is one of the pillars of waqf that has responsibilities and obligations in maintaining, maintaining, and developing nwaqf, and distributes the results and benefits of the waqf to the targetnwaqf. Often, the waqf assets managed by Nadzir do not have sufficient capacity, so that the wakaf assets managed are not optimal and cannot provide benefit for the targetnwaqf. In the jurisprudence book, the requirements to be Nazir, apart from having to be Islam and mukallaf, Nadzir must also have the ability to manage waqf and be trustworthy, honest, and fair. (Kasdi, 2016) 
If the waqf property is managed optimally and Nazhir has the ability to manage waqf, it needs political support from the government in the context of empowermentncivil society. The potential of waqf in empowering people is encouraged by the government in terms of politics with regulationsnwaqf legislation so that it can function productively. For example, Dompet Dhuafa Republika innovation from civil society is a form of concern that arises from society. Muslims have the freedom to manage wealth in accordance with Islamic financial principles. This system is not only a profitable community but also supports government programs. Such circumstances will open opportunities for empowermentnproductive waqf as an effort to increase people's welfare (Kasdi, 2015).

To optimize waqf property for the realization of the purpose of waqf, namely as a means and infrastructure to improve quality of life and human resources, it is necessary to change understandingnpeople regarding waqf who think that waqf assets are limited to immovable assets such as graves, mosques, foundations, and Islamic boarding schools that cannot be produced. Perwakaf Legislation Regulations, namely Law No.41 of 2004 concerning Waqf and Regulations, Government No. 42 of 2006 concerning ImplementationnWaqf. The two regulations both have urgency apartnthe importance of mahdha worship, and emphasized that it is necessary to empower waqf productively for our interest, namely the welfare of the people.

\section{CONCLUSION}

Waqf plays an important role as an empowering instrument for the economy of people. Waqf plays an important role in economic development and social and community culture. There are four problems with Islamic missionary movements through waqf. First, poverty, both in terms of economy or limitationsnphysical means and needs that give birth to a culture of poverty. Second, the result of povertynhence the signs of underdevelopment appear. Third, there is the emergence of an involutive and exclusive nature. Fourth, the weakness of progression to accommodate participation and the weakness of the cooperation mechanism to smooth it outnstruggle. Thus, waqf is an alternative that can provide solutions to these four problems. Thus, it is necessary to optimize waqf management.

Waqf requires a strategy that can develop a productive waqf. According to Eddy Khairani, there are several things that can be donenin the productive waqf development strategy, namely, regulation of laws and regulationsnwaqf; Socialization of regulationsnper-Waqf Law and a new paradigm of waqf, certification, inventory, and advocacy of waqf assets, enhancing the quality of Nazhir and waqf institutions, facilitating partnershipnproductive waqf investment, and facilitating the formation of the Indonesian Waqf Board (BWI). 


\section{REFERENCES}

Al-hadi, A. A. (2009). Upaya pemberdayaan tanah wakaf produktif bagi kesejahteraan ummat, 4(1), 95-107.

Antonio, M. S. (2007). Bank Syariah daru Teori ke Praktek. Jakarta: Gema Insani.

Bakhri, A., \& Srifariyati. (2017). Peran Wakaf Produktif Dalam Pemberdayaan Ekonomi. Jurnal Madaniyah, 1, 129-153.

Dikuraisyin, B. (2020). Manajemen Aset Wakaf Berbasis Kearifan Lokal Dengan Pendekatan Sosio-Ekonomi di Lembaga Wakaf Sabilillah Malang. Jurnal Zakat Dan Wakafakat, 7(2), 100-116.

Hadi, S. (2017). Pemberdayaan ekonomi melalui wakaf. Jurnal Zakat Dan Wakaf, 4(2), 229-244.

Indriati, D. S. (2017). Urgensi Wakf Produktif Dalam Pembangunan Ekonomi Masyarakat. Jurnal Ilmiah Al- Syir'ah, 15(2), 94-114.

Kasdi, Abdurrohman. (2014). Model Pemberdayaan Wakaf Produktif di Indonesia. ZISWAF, 1(1), 108-122.

Kasdi, Abdurrohman. (2015). Peran Wakaf Produkif dalam Pengembangan Pendidikan. Jurnal Pendidikan Islam, 3(2), 433-452.

Kasdi, Abdurrohman. (2016). Pergeseran Makna dan Pemberdayaan Wakaf (dari Konsumtif ke Produktif). Jurnal Zakat Dan Wakaf, 3(1), 1-17.

Kasdi, Abdurrohman. (2017). Fiqih Wakaf: Dari Wakaf Klasik Hingga Wakaf Produktif. (U. Farida, Ed.). Yogyakarta: Idea Press.

Khairani, E. (2013). Strategi Pengembangan Wakaf Produktif. Yogyakarta: CV. Cahaya Islam.

Kurniawan, M. (n.d.). Wakaf produktif dan pemberdayaan ekonomi umat.

Medias, F. (2010). Wakaf Produktif Dalam Perspektif Ekonomi Islam. Jurnal Ekonomi Islam La Riba, Vol IV, No.

Pemberdayaan Wakaf, D. (2007). Panduan Pemberdayaan Tanah Wakaf Produktif Strategis di Indonesia. Jakarta: Departemen Agama RI.

Qahaf, M. (2006). Al Waqfu al islami: tatawuruhu, idaratuhu, tanmiyatuhu. Beirut: Dar al Fikr. 
Ardiyansyah, Kasdi, : Strategies and Optimizing the Role of Productive

Sugiyono. (2005). Memahami Penelitian Kualitatif. Bandung: CV. Alfabeta.

Wahid, A. (2010). Sukuk Memahami dan Membedah Obligasi Pada Perbankan Syariah. Yogyakarta: Ar Ruzz Media. 